\title{
Interactions between common heterotrophic protists and the dinoflagellate Tripos furca: implication on the long duration of its red tides in the South Sea of Korea in 2020
}

\author{
Se Hee Eom ${ }^{1}$, Hae Jin Jeong ${ }^{1,2, *}$, Jin Hee $\mathrm{Ok}^{1}$, Sang Ah Park ${ }^{1}$, Hee Chang Kang ${ }^{1}$, Ji Hyun \\ You $^{1}$, Sung Yeon Lee ${ }^{1}$, Yeong Du Yoo ${ }^{3}$, An Suk Lim ${ }^{4}$ and Moo Joon Lee ${ }^{5}$ \\ ${ }^{1}$ School of Earth and Environmental Sciences, College of Natural Sciences, Seoul National University, Seoul 08826, Korea \\ ${ }^{2}$ Research Institute of Oceanography, Seoul National University, Seoul 08826, Korea \\ ${ }^{3}$ Department of Marine Biotechnology, College of Ocean Sciences, Kunsan National University, Kunsan 54150, Korea \\ ${ }^{4}$ Division of Life Science \& Plant Molecular Biology and Biotechnology Research Center, Gyeongsang National University, \\ Jinju 52828, Korea \\ ${ }^{5}$ Department of Marine Biotechnology, Anyang University, Incheon 23038, Korea
}

The mixotrophic dinoflagellate Tripos furca causes red tides in the waters of many countries. To understand its population dynamics, mortality due to predation as well as growth rate should be assessed. Prior to the present study, the heterotrophic dinoflagellates Noctiluca scintillans, Polykrikos kofoidii, Protoperidinium steinii, and mixotrophic dinoflagellate Fragilidium subglobosum were known to ingest T. furca. However, if other common heterotrophic protists are able to feed on T. furca has not been tested. We explored interactions between T. furca and nine heterotrophic dinoflagellates and one naked ciliate. Furthermore, we investigated the abundance of T. furca and common heterotrophic protists in coastal-offshore waters off Yeosu, southern Korea, on Jul 31, 2020, during its red tide. Among the tested heterotrophic protists, the heterotrophic dinoflagellates Aduncodinium glandula, Luciella masanensis, and Pfiesteria piscicida were able to feed on T. furca. However, the heterotrophic dinoflagellates Gyrodiniellum shiwhaense, Gyrodinium dominans, Gyrodinium jinhaense, Gyrodinium moestrupii, Oblea rotunda, Oxyrrhis marina, and the naked ciliate Rimostrombidium sp. were unable to feed on it. However, T. furca did not support the growth of A. glandula, L. masanensis, or P. piscicida. Red tides dominated by T. furca prevailed in the South Sea of Korea from Jun 30 to Sep 5, 2020. The maximum abundance of heterotrophic dinoflagellates in the waters off Yeosu on Jul 31, 2020, was as low as $5.0 \mathrm{cells} \mathrm{mL}^{-1}$, and A. glandula, $L$. masanensis, and P. piscicida were not detected. Furthermore, the abundances of the known predators $F$. subglobosum, $N$. scintillans, P. kofoidii, and Protoperidinium spp. were very low or negligible. Therefore, no or low abundance of effective predators might be partially responsible for the long duration of the T. furca red tides in the South Sea of Korea in 2020.

Key Words: ciliate; grazer; harmful algal bloom; heterotrophic dinoflagellate; red tide

\footnotetext{
(c) (P) This is an Open Access article distributed under the terms of the Creative Commons Attribution Non-Commercial License (http://creativecommons.org/licenses/by-nc/3.0/) which permits unrestricted non-commercial use, distribution, and reproduction in any medium, provided the original work is properly cited.
}

Received December 29, 2020, Accepted February 22, 2021

*Corresponding Author

E-mail: hjjeong@snu.ac.kr

Tel: +82-2-880-6746, Fax: +82-2-874-9695 


\section{INTRODUCTION}

Red tides, which are discolorations due to plankton blooms, often cause large-scale morbidity and mortality of marine organisms such as fish, sea birds, and marine mammals (Landsberg 2002, Shumway et al. 2003, Flewelling et al. 2005, Jessup et al. 2009), as well as economic losses to aquaculture and tourism industries (Shumway 1990, Anderson 1997, Azanza et al. 2005, Jeong et al. 2021). To minimize financial losses, it is critical to understand and forecast the outbreak, persistence, and decline of red tides (Jeong et al. 2015). In models for predicting red tide dynamics, growth and mortality due to predation are the most important parameters.

The cosmopolitan dinoflagellate Tripos furca is renowned for causing red tides across the waters of many countries (Dodge and Marshall 1994, Horner et al. 1997, Tomas 1997). This dinoflagellate can grow autotrophically or mixotrophically (Smalley et al. 1999, 2003, Smalley and Coats 2002, Baek et al. 2008). Tripos furca is known to prey on the choreotrich ciliates Strobilidium spp., small tintinnids with sizes of 10-40 $\mu \mathrm{m}$ in diameter, and the mixotrophic ciliate Mesodinium rubrum (Bockstahler and Coats 1993, Smalley et al. 1999, Stoecker 1999, Johnson et al. 2013). Meanwhile, the heterotrophic dinoflagellates Noctiluca scintillans, Polykrikos kofoidii, Protoperidinium steinii, and mixotrophic dinoflagellate Fragilidium subglobosum are known to feed on this species (Hansen and Nielsen 1997, Jeong et al. 2001, Olseng et al. 2002, Drits et al. 2013). However, predation by many other common heterotrophic protists on T. furca has not been explored. To understand its red tide dynamics, feeding by common heterotrophic protists on T. furca should be investigated.

Tripos furca is one of the dinoflagellates that frequently cause red tides in Korean waters (Baek et al. 2011, Lee et al. 2013, Jeong et al. 2017). It usually causes red tides during spring and summer around the Korean coast, mainly at $24.6-25.1^{\circ} \mathrm{C}$, although it has been recorded as being abundant at $17.5-28.4^{\circ} \mathrm{C}$ (Jeong et al. 2013). This species caused long-lasting red tides in the South Sea of Korea from Jun 30 to Sep 5, 2020 (NFRDI data; http:// www.nifs.go.kr/portal/redtideInfo). It is worthwhile to explore the roles of potential predators in the long duration of $T$. furca red tides because high grazing impact by heterotrophic protists sometimes causes cessation of red tides (Watras et al. 1985, Nakamura et al. 1992, Jeong and Latz 1994, Turner 2006, Stoecker et al. 2008, Yoo et al. 2013, Yang et al. 2019). If there was a shortage of effective predators on this dinoflagellate, a low grazing im- pact might be partially responsible for the long duration of these red tides. Therefore, whether there were effective predators on T. furca during its red tides of the year 2020 should be investigated.

The heterotrophic dinoflagellates Gyrodinium dominans, Oblea rotunda, Oxyrrhis marina, Pfiesteria piscici$d a$, and naked ciliates are common heterotrophic protists in the waters of many countries, including Korea (Wood 1954, Hansen 1991, Jakobsen and Tang 2002, Mason et al. 2007, Lowe et al. 2010, Lim et al. 2017, Ok et al. 2017). Nevertheless, the worldwide distribution of these heterotrophic protists and whether they ingest T. furca has not been explored.

In the present study, we explored the interactions between T. furca and nine heterotrophic dinoflagellates (Aduncodinium glandula, Gyrodiniellum shiwhaense, Gyrodinium dominans, Gyrodinium jinhaense, Gyrodinium moestrupii, Luciella masanensis, Oblea rotunda, Oxyrrhis marina, and Pfiesteria piscicida), and one naked ciliate Rimostrombidium sp. These heterotrophic protists cover a wide range of size and feeding mechanisms (Hansen 1992, Strom and Buskey 1993, Sonntag et al. 2006, Jeong et al. 2007, 2011, Roberts et al. 2011, Jang et al. 2016, Kang et al. 2020). Furthermore, we investigated the abundance of T. furca and common heterotrophic protists in coastal-offshore waters off Yeosu in the South Sea of Korea on Jul 31, 2020, when huge T. furca red tides prevailed in the South Sea of Korea. The results of the present study will provide a better understanding of interactions between T. furca and heterotrophic protists and their population dynamics.

\section{MATERIALS AND METHODS}

\section{Preparation of experimental organisms}

Tripos furca was isolated from surface waters off the coast of Dundeok, Geoje, southern Korea (34 $51^{\prime} 26^{\prime \prime}$ N, $128^{\circ} 28^{\prime} 34^{\prime \prime}$ E) using plankton samplers in August 2018, when the water temperature and salinity were $28.5^{\circ} \mathrm{C}$ and 32.5 , respectively (Table 1 ). The collected samples were gently screened using a $100 \mu \mathrm{m}$ sieve and $10 \mu \mathrm{m}$ Nitex mesh. By conducting two consecutive single-cell isolations, a T. furca TFDD1808 clonal culture was established. When $T$. furca concentration had increased sufficiently, it was transferred into 32,270 , and $500-\mathrm{mL}$ polycarbonate (PC) bottles filled with fresh half-diluted L1 medium. The bottles were placed at $20^{\circ} \mathrm{C}$, under a $14: 10 \mathrm{~h}$ light : dark cycle, on a shelf illuminated with cool white fluorescent 
lights of $20 \mu \mathrm{mol}$ photons $\mathrm{m}^{-2} \mathrm{~s}^{-1}$. Only cultures reaching the exponential growth stage were used in the study.

The heterotrophic dinoflagellates A. glandula, G. shiwhaense, G. dominans, G. jinhaense, G. moestrupii, L. masanensis, $O$. rotunda, O. marina, and P. piscicida, isolated from plankton samples collected from coastal waters off Geoje, Jeongok, Jinhae, Kunsan, Masan, Neuse River, and Saemankeum from 1998 to 2019, were used in this study (Table 1). Two consecutive single-cell isolations were conducted to establish each heterotrophic dinoflagellate species clonal culture, except for that of $P$. piscicida CCMP2091, which was acquired from the National Center for Marine Algae and Microbiota, USA. The naked ciliate Rimostrombidium sp. was isolated from plankton samples collected in a bucket from the coastal waters off Saemankeum, Korea, in July 2020, when the water temperature and salinity were $27.1^{\circ} \mathrm{C}$ and 18.8 , respectively (Table 1). A clonal culture for Rimostrombidium sp. was also set up with two serial single-cell isolations, and its volume increased from 6-well plate chambers to 50 and 270-mL PC bottles, with a diet of Heterocapsa rotundata as prey (ca. 5,000 cells $\mathrm{mL}^{-1} \mathrm{~d}^{-1}$ ).

The carbon content of T. furca TFDD1808 (1.7 ng C per cell) was estimated from the cell volume, according to the equation proposed by Menden-Deuer and Lessard (2000). Using the same calculation, the carbon contents of all predator species in the present study were also evaluated from the cell volume. The cell volumes of the heterotrophic predators were assessed using the methods of Jang et al. (2016) for A. glandula; Ok et al. (2017) for G. shiwhaense; Kang et al. (2020) for G. dominans, G. jinhaense, and G. moestrupii; Jeong et al. (2007) for L. masanensis and P. piscicida; You et al. (2020) for O. rotunda and $O$. marina; and this study for Rimostrombidium sp. (Table 1).

\section{Interactions between Tripos furca and heterotro- phic protists}

This experiment was designed to examine whether each heterotrophic dinoflagellate or ciliate fed on T. furca TFDD1808, after mixing T. furca with potential predator species (Table 2). In this experiment, predation or other interactions between $T$. furca and the target heterotrophic protist were observed.

Dense cultures of T. furca (ca. 2,000 cells $\mathrm{mL}^{-1}$ ) and the target heterotrophic protist were added to individual 42-mL PC bottles (Table 2). One experiment bottle con-

Table 1. Information on the isolation and maintenance of the heterotrophic protists and Tripos furca used in the present study

\begin{tabular}{|c|c|c|c|c|c|c|c|c|c|}
\hline Organism (strain name) & Location & Time & $T$ & $\mathrm{~S}$ & Type & FM & ESD & PS & PC \\
\hline \multicolumn{10}{|l|}{ Predator } \\
\hline $\begin{array}{l}\text { Aduncodinium glandula } \\
\text { (AGMS1303) }\end{array}$ & Masan, Korea & Mar 2013 & 8.1 & 30.3 & HTD & $\mathrm{PE}$ & 21.0 & As & $1,000-2,000$ \\
\hline $\begin{array}{l}\text { Gyrodiniellum shi- } \\
\text { whaense (GSGJ1408) }\end{array}$ & Geoje, Korea & Aug 2014 & 26.5 & 33.4 & HTD & $\mathrm{PE}$ & 10.5 & Ac & $\sim 20,000$ \\
\hline $\begin{array}{l}\text { Gyrodinium dominans } \\
\text { (GDJK1907) }\end{array}$ & Jeongok, Korea & Jul 2019 & 25.2 & 31.9 & HTD & EG & 11.6 & Ac & $10,000-20,000$ \\
\hline $\begin{array}{l}\text { Gyrodinium jinhaense } \\
\text { (GSJH1710) }\end{array}$ & Jinhae, Korea & Oct 2017 & 21.6 & 32.5 & HTD & EG & 10.2 & Heat-killed Ds & $10,000-20,000$ \\
\hline $\begin{array}{l}\text { Gyrodinium moestrupii } \\
\text { (GMSMK0910) }\end{array}$ & Saemankeum, Korea & Oct 2009 & 21.2 & 31.0 & HTD & EG & 16.0 & $\mathrm{Am}$ & $10,000-20,000$ \\
\hline $\begin{array}{l}\text { Luciella masanensis } \\
\text { (LMJH1607) }\end{array}$ & Jinhae, Korea & Jul 2016 & 22.6 & 30.7 & HTD & PE & 13.5 & Api & $\sim 20,000$ \\
\hline $\begin{array}{l}\text { Oblea rotunda } \\
\text { (ORJH1504) }\end{array}$ & Jinhae, Korea & Apr 2015 & 12.6 & 31.2 & HTD & PA & 21.6 & Ac & $\sim 10,000$ \\
\hline $\begin{array}{l}\text { Oxyrrhis marina } \\
\text { (OMKS0105) }\end{array}$ & Kunsan, Korea & May 2001 & 16.0 & 27.7 & HTD & EG & 15.6 & Ac & $10,000-20,000$ \\
\hline $\begin{array}{l}\text { Pfiesteria piscicida } \\
\text { (CCMP2091) }\end{array}$ & Neuse River, USA & Jan 1998 & - & - & HTD & PE & 13.5 & Ac & $\sim 5,000$ \\
\hline $\begin{array}{l}\text { Rimostrombidium sp. } \\
\text { (RSSMK2007) }\end{array}$ & Saemankeum, Korea & Jul 2020 & 27.1 & 18.8 & $\mathrm{NC}$ & FF & 29.8 & $\mathrm{Hr}$ & $\sim 5,000$ \\
\hline \multicolumn{10}{|l|}{ Prey } \\
\hline Tripos furca (TFDD1808) & Dundeok, Geoje, Korea & Aug 2018 & 28.5 & 32.5 & MTD & EG & 28.9 & - & - \\
\hline
\end{tabular}

$\mathrm{T}$, temperature $\left({ }^{\circ} \mathrm{C}\right) ; \mathrm{S}$, salinity; FM, feeding mechanism; ESD, equivalent spherical diameter $(\mu \mathrm{m}) ; \mathrm{PS}$, prey species; PC, prey concentration (cells $\mathrm{mL}^{-1}$ ); HTD, heterotrophic dinoflagellate; PE, peduncle feeder; As, Akashiwo sanguinea; Ac, Amphidinium carterae; EG, engulfment feeder; Ds, Dunaliella salina; Am, Alexandrium minutum (CCMP113); Api, Apistonema-like sp. (CCMP3085); PA, pallium feeder; -, not available; NC, naked ciliate; $\mathrm{FF}$, filter feeder; $\mathrm{Hr}$, Heterocapsa rotundata; MTD, mixotrophic dinoflagellate. 
taining prey and predator, one prey control, and one predator control bottle were set up for the target heterotrophic protist. All the bottles, except for the ones with the $A$. glandula predator, were placed on a rotating wheel at $0.00017 \mathrm{~g}(0.9 \mathrm{rpm})$, while those for the A. glandula predator were placed on a shelf. All the bottles were incubated at $20^{\circ} \mathrm{C}$, under a $14: 10 \mathrm{~h}$ light : dark cycle, and illuminated with cool white fluorescent light of $20 \mu \mathrm{mol}$ photons $\mathrm{m}^{-2} \mathrm{~s}^{-1}$.

Aliquots of $3 \mathrm{~mL}$ were taken from each bottle after 2, 24, and $48 \mathrm{~h}$ of incubation period, and placed into separate wells of 6-well plate chambers. More than 30 cells of each predator species were transferred into plate chambers and tracked for a minimum of 2 min under a dissecting microscope at 20-63× magnification to test whether the target predator fed on T. furca or not. The predator cells with and without ingested T. furca cells in their protoplasms were photographed on confocal dishes with cover glasses at 200-630× magnification using a digital camera (Zeiss-AxioCam 506; Carl Zeiss Ltd., Göttingen, Germany) attached to an inverted light microscope (Zeiss-Axiovert 200 M; Carl Zeiss Ltd.). The feeding process of the heterotrophic protists that successfully ingested T. furca cells was recorded and captured using an identical digital camera.

\section{Abundance of Tripos furca and common hetero- trophic protists in the waters off Yeosu}

The two stations (Stations 501 and 504) were located in the nearshore and offshore regions off Yeosu in the South Sea of Korea (Fig. 1). The water depth for both sampling stations was approximately $20 \mathrm{~m}$. Station 501 was located approximately $20 \mathrm{~km}$ south of the Seumjin River; thus, the salinity at this station sometimes reduced due to freshwater input (Jeong et al. 2017). Water temperature, salinity, dissolved oxygen (DO), and $\mathrm{pH}$ for each sam-

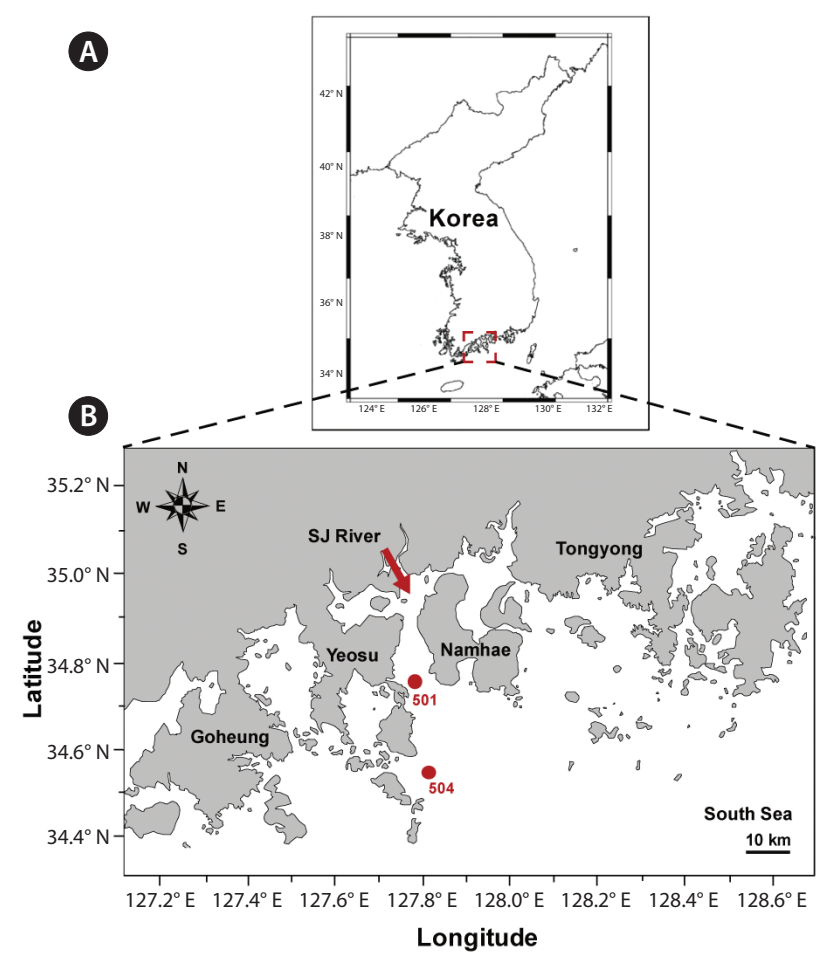

Fig. 1. Maps of the study region and the sampling stations (A \& B). The arrow between Yeosu and Namhae indicates Seomjin (SJ) River.

pling depth were measured using a YSI Professional Plus instrument (YSI Inc., Yellow Springs, OH, USA).

Water samples at Stations 501 and 504 were collected using water samplers at depths of $0,5,10,15$, and $20 \mathrm{~m}$. The sampling time was 13:00 at Station 501 and 13:40 at Station 504. Plankton samples for counting were collected into 500-mL polyethylene bottles and preserved with acidic Lugol's solution. To clarify the abundance of $T$. furca and heterotrophic protists, the fixed samples were concentrated by $1 / 5-1 / 10$, using the settling and siphoning method (Welch 1948). After thorough mixing, all or a

Table 2. Experimental design

\begin{tabular}{|c|c|c|c|}
\hline Prey species & Prey density & Predator species & Predator density \\
\hline \multirow[t]{10}{*}{ Tripos furca } & $800-1,100$ & Aduncodinium glandula & 650 \\
\hline & & Gyrodiniellum shiwhaense & 3,600 \\
\hline & & Gyrodinium dominans & 800 \\
\hline & & Gyrodinium jinhaense & 400 \\
\hline & & Gyrodinium moestrupii & 900 \\
\hline & & Luciella masanensis & 2,000 \\
\hline & & Oblea rotunda & 700 \\
\hline & & Oxyrrhis marina & 1,500 \\
\hline & & Pfiesteria piscicida & 2,000 \\
\hline & & Rimostrombidium sp. & 280 \\
\hline
\end{tabular}

The numbers in the prey and predator density columns are the initial densities (cells $\mathrm{mL}^{-1}$ ). 
minimum of 100 cells of $T$. furca and each heterotrophic protist species in one to ten 1-mL Sedgwick-Rafter chambers were enumerated under a light microscope.

\section{RESULTS}

\section{Interactions between Tripos furca and heterotro- phic protists}

The heterotrophic dinoflagellates A. glandula, L. masa- nensis, and P. piscicida were able to feed on T. furca. However, the heterotrophic dinoflagellates G. shiwhaense, G. dominans, G. jinhaense, G. moestrupii, O. rotunda, O. marina, and the naked ciliate Rimostrombidium sp. were unable to feed on the prey (Table 3, Figs $2 \& 3$ ). Cells of A. glandula, L. masanensis, and P. piscicida successfully ingested T. furca using peduncles (Fig. 2). Multiple cells of L. masanensis or P. piscicida attacked a T. furca cell together (Fig. 2). However, G. jinhaense, G. moestrupii, O. rotunda, and $O$. marina attempted to capture $T$. furca, but failed to do so (Table 3, Fig. 3). Moreover, G. shiwhaense,

Table 3. Taxa, size, and response of potential heterotrophic dinoflagellate and naked ciliate predators offered to Tripos furca (TFDD1808)

\begin{tabular}{|c|c|c|c|c|c|}
\hline & FM & $\mathrm{ESD}(\mu \mathrm{m})$ & Physical attack & Successful capture & Growth \\
\hline \multicolumn{6}{|l|}{ Heterotrophic dinoflagellate } \\
\hline Gyrodinium jinhaense & EG & 10.2 & ० & $\times$ & $\mathrm{N}$ \\
\hline Gyrodiniellum shiwhaense & $\mathrm{PE}$ & 10.5 & $x$ & $\times$ & $\mathrm{N}$ \\
\hline Gyrodinium dominans & EG & 11.6 & $\times$ & $x$ & $\mathrm{~N}$ \\
\hline Luciella masanensis & $\mathrm{PE}$ & 13.5 & $\circ$ & ० & $\mathrm{N}$ \\
\hline Pfiesteria piscicida & $\mathrm{PE}$ & 13.5 & ० & ० & $\mathrm{N}$ \\
\hline Oxyrrhis marina & EG & 15.6 & ○ & $x$ & $\mathrm{~N}$ \\
\hline Gyrodinium moestrupii & EG & 16.0 & $\circ$ & $\times$ & $\mathrm{N}$ \\
\hline Aduncodinium glandula & $\mathrm{PE}$ & 21.0 & $\circ$ & $\circ$ & $\mathrm{N}$ \\
\hline Oblea rotunda & $\mathrm{PA}$ & 21.6 & $\circ$ & $x$ & $\mathrm{~N}$ \\
\hline \multicolumn{6}{|l|}{ Naked ciliate } \\
\hline Rimostrombidium sp. & FF & 29.8 & $\times$ & $\times$ & $\mathrm{N}$ \\
\hline
\end{tabular}

FM, feeding mechanism; ESD, equivalent spherical diameter $(\mu \mathrm{m})$; EG, engulfment feeder; $\circ$, observed; $\times$, not observed; $N$, no growth; $P E$, peduncle feeder; PA, pallium feeder; FF, filter feeder.

Table 4. The abundances (cells $\mathrm{mL}^{-1}$ ) of Tripos furca, heterotrophic dinoflagellates, and tintinnid and naked ciliates in five depths of Stations 501 and 504 located off Yeosu in South Sea of Korea on Jul 31, 2020

\begin{tabular}{|c|c|c|c|c|c|c|c|c|c|c|}
\hline \multirow{2}{*}{ Taxon } & \multicolumn{5}{|c|}{ Station 501} & \multicolumn{5}{|c|}{ Station 504} \\
\hline & $\mathbf{0 ~ m}$ & $5 \mathrm{~m}$ & $10 \mathrm{~m}$ & $15 \mathrm{~m}$ & $20 \mathrm{~m}$ & $\mathbf{0 m}$ & $5 \mathrm{~m}$ & $10 \mathrm{~m}$ & $15 \mathrm{~m}$ & $20 \mathrm{~m}$ \\
\hline \multicolumn{11}{|l|}{ Mixotrophic dinoflagellate } \\
\hline Tripos furca & 23.7 & 130.8 & 19.4 & 0.9 & 22.2 & 59.2 & 41.4 & 3.0 & 1.5 & - \\
\hline \multicolumn{11}{|l|}{ Heterotrophic dinoflagellate } \\
\hline Gyrodinium sp. (ca. $60-80 \mu \mathrm{m})$ & - & - & - & - & - & - & 2.0 & - & - & - \\
\hline Gyrodinium sp. $(>80 \mu \mathrm{m})$ & - & 0.3 & - & - & - & - & 2.0 & 0.6 & - & - \\
\hline Noctiluca scintillans & - & - & - & - & - & - & - & 0.6 & - & - \\
\hline Protoperidinium spp. & - & - & 0.5 & - & - & 0.8 & 1.0 & - & - & - \\
\hline \multicolumn{11}{|l|}{ Tintinnid ciliate } \\
\hline Leprotintinnus nordqvistii & - & - & - & - & - & - & 2.0 & 1.2 & - & 0.7 \\
\hline Tintinnopsis akkeshiensis & - & - & - & - & - & 0.8 & - & - & - & - \\
\hline Tintinnopsis kofoidii & - & - & - & - & - & 0.8 & - & - & - & - \\
\hline Tintinnopsis lohmanni & - & - & - & 0.9 & - & - & - & - & - & - \\
\hline Tintinnopsis radix & - & - & 0.5 & - & - & - & - & - & - & - \\
\hline Tintinnopsis tubulosoides & - & - & - & - & - & - & - & - & - & 1.4 \\
\hline \multicolumn{11}{|l|}{ Naked ciliate } \\
\hline Naked ciliates $(>50 \mu \mathrm{m})$ & - & - & - & - & - & 1.7 & - & 1.8 & - & - \\
\hline $\mathrm{T}$ & 25.6 & 22.4 & 21.5 & 20.6 & 20.0 & 26.7 & 23.5 & 21.4 & 19.9 & 17.1 \\
\hline S & 14.26 & 28.01 & 31.87 & 32.96 & 33.17 & 23.05 & 29.90 & 31.51 & 32.70 & 34.42 \\
\hline DO & 7.22 & 6.32 & 6.11 & 6.30 & 6.15 & 8.95 & 7.22 & 5.65 & 6.36 & 8.09 \\
\hline $\mathrm{pH}$ & 8.44 & 8.23 & 8.24 & 8.14 & 8.14 & 8.74 & 8.47 & 8.36 & 8.33 & 8.38 \\
\hline
\end{tabular}

- , not detected; T, temperature $\left({ }^{\circ} \mathrm{C}\right) ; \mathrm{S}$, salinity; DO, dissolved oxygen ( $\mathrm{mg} \mathrm{L}^{-1}$ ). 

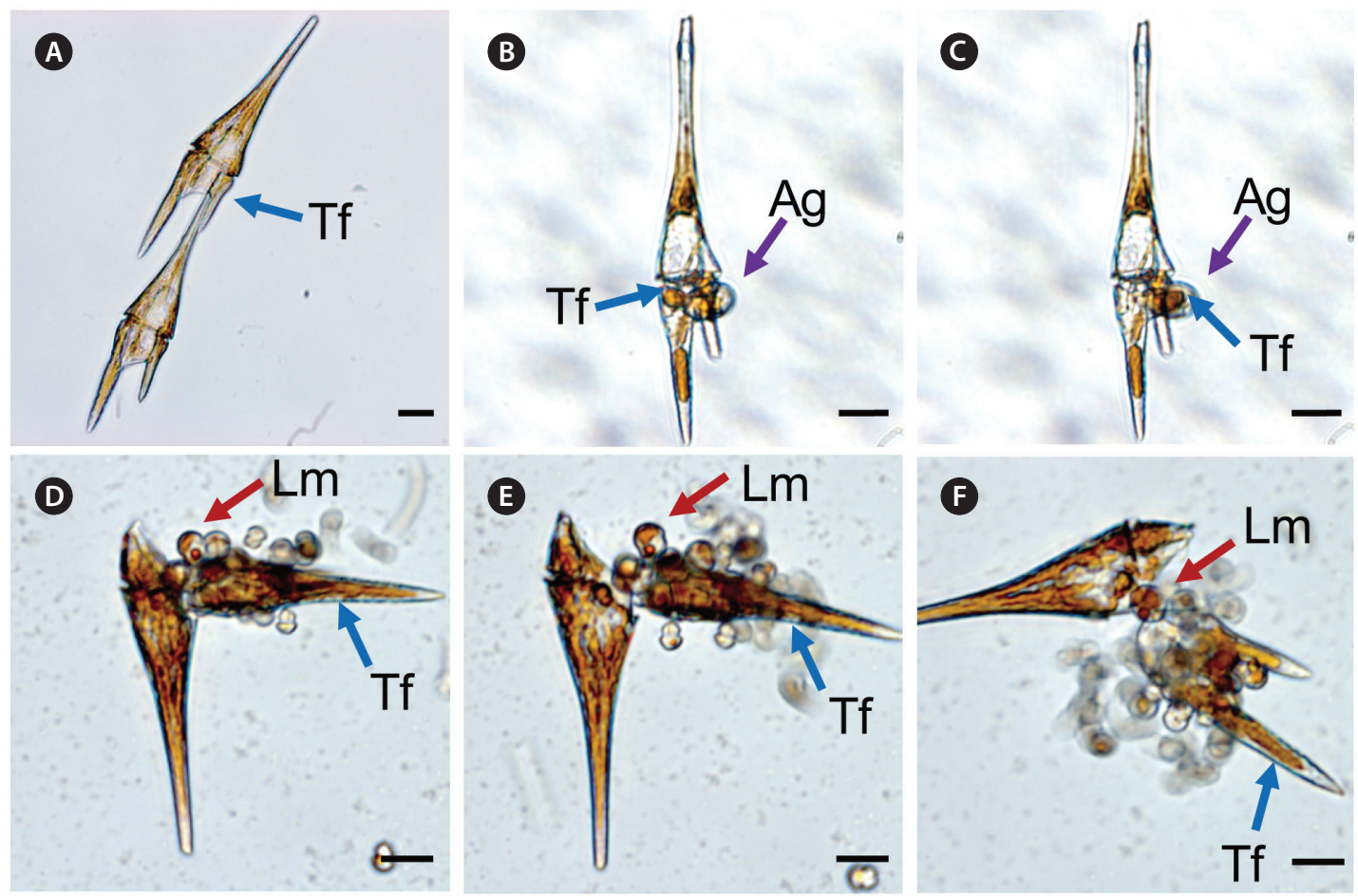

(
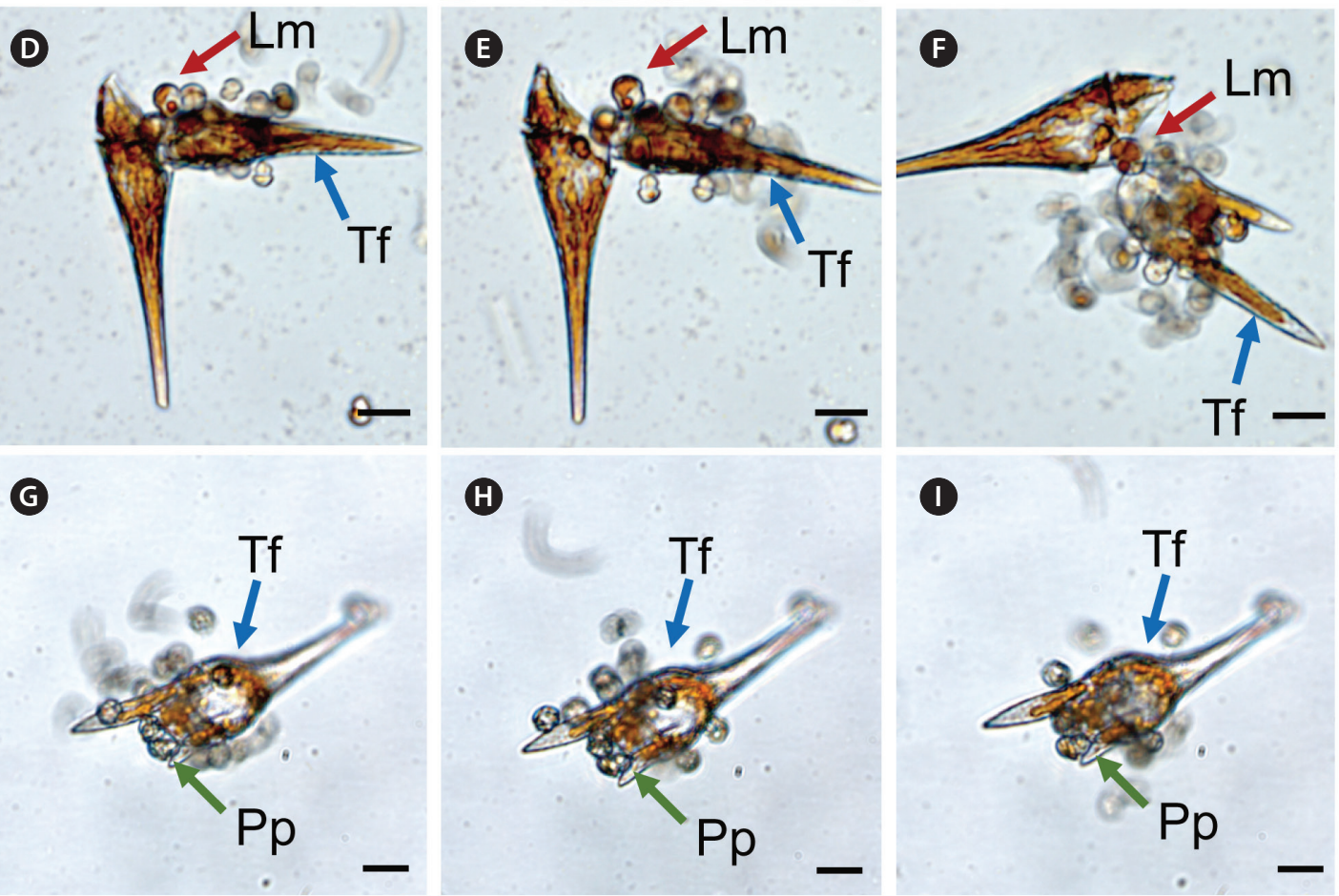

Fig. 2. Successful feeding process of heterotrophic protists on Tripos furca (Tf) recorded using a digital camera attached to an inverted light microscope. (A) Two Tf cells as prey control. (B \& C) Feeding by Aduncodinium glandula (Ag) on a Tf cell. An Ag cell fed on a Tf cell using peduncle. (DF) Feeding by Luciella masanensis ( $\mathrm{Lm}$ ) on a Tf cell. Multiple Lm cells fed on a Tf cell using peduncles. (G-I) Feeding by Pfiesteria piscicida (Pp) on a Tf cell. Multiple Pp cells fed on a Tf cell using peduncles. Scale bars represent: A-I, $20 \mu \mathrm{m}$.

G. dominans, and Rimostrombidium sp. did not attack T. furca (Table 3, Fig. 3). Regardless of capture by potential predators, T. furca did not support positive growth of any of the heterotrophic protists tested in the present study; thus, $T$. furca may be an undesirable food source for the common heterotrophic protists (Table 3 ).

\section{Abundance of Tripos furca and common hetero- trophic protists in the waters off Yeosu on Jul 31, 2020}

Tripos furca caused huge red tides in the South Sea of
Korea from Jun 30 to Sep 5, 2020 (NFRDI data; http:// www.nifs.go.kr/portal/redtideInfo). The water temperature and salinity at Station 501 on Jul 31, 2020, ranged from 20.0 to $25.6^{\circ} \mathrm{C}$ and 14.26 to 33.17 , respectively, while those at Station 504 ranged from 17.1 to $26.7^{\circ} \mathrm{C}$ and 23.05 to 34.42 , respectively (Table 4). The DO and pH at Station 501 on Jul 31, 2020, ranged from 6.11 to $7.22 \mathrm{mg} \mathrm{L}^{-1}$ and 8.14 to 8.44 , respectively, while those at Station 504 ranged from 5.65 to $8.95 \mathrm{mg} \mathrm{L}^{-1}$ and 8.33 to 8.74 , respectively (Table 4). The abundance of T. furca at Station 501 was 0.9 to 130.8 cells $\mathrm{mL}^{-1}$, but that at Station 504 was 0 to 59.2 cells $\mathrm{mL}^{-1}$ (Table 4 ). The abundance of the hetero- 

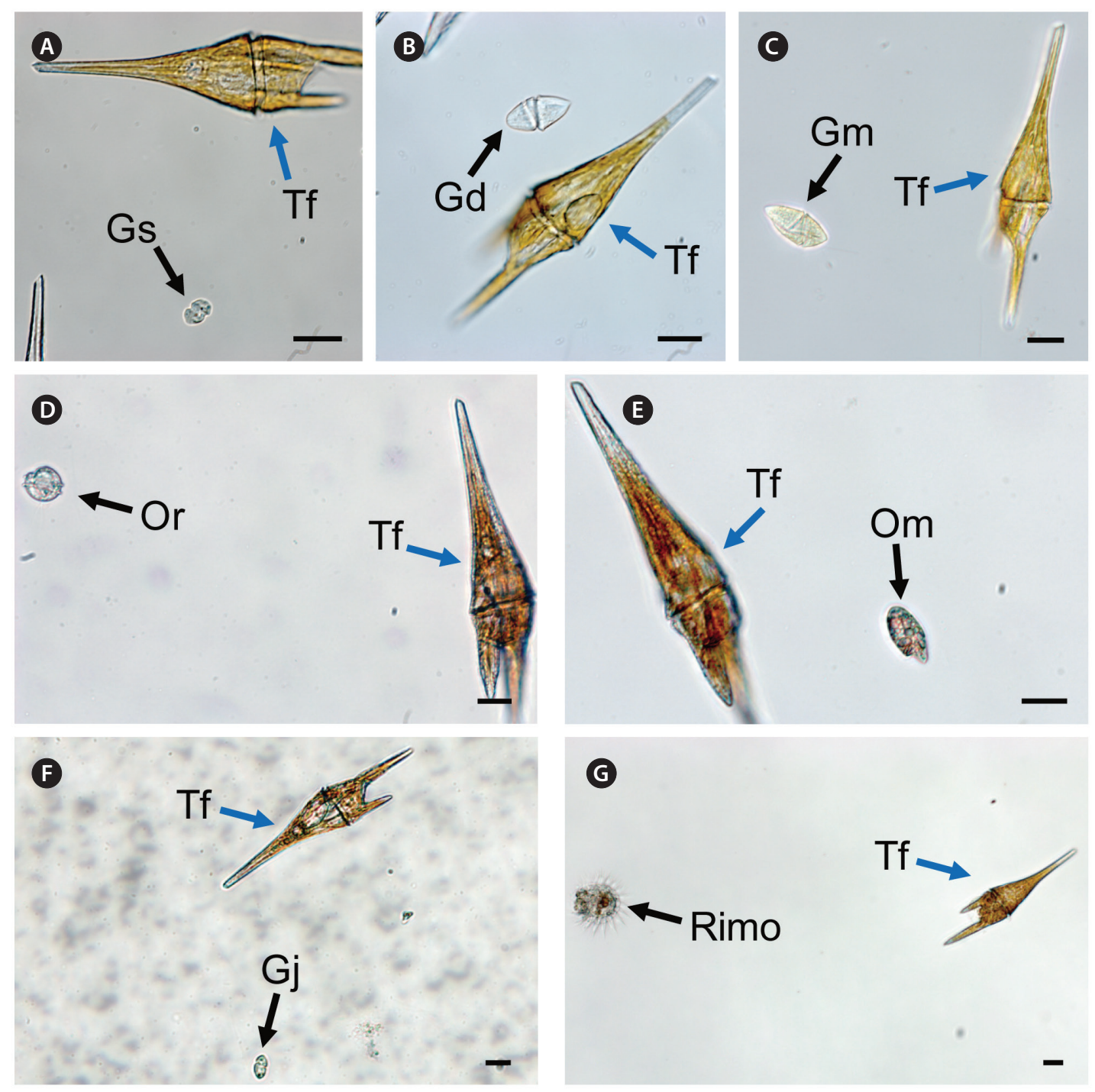

Fig. 3. Unsuccessful feeding process of heterotrophic dinoflagellates on Tripos furca (Tf) recorded using a digital camera attached to an inverted light microscope. (A) Gyrodiniellum shiwhaense (Gs) did not feed on Tf. (B) Gyrodinium dominans (Gd) did not feed on Tf. (C) Gyrodinium moestrupii $(\mathrm{Gm})$ did not feed on Tf. (D) Oblea rotunda (Or) did not feed on Tf. (E) Oxyrrhis marina (Om) did not feed on Tf. (F) Gyrodinium jinhaense (Gj) did not feed on Tf. (G) Rimostrombidium sp. (Rimo) did not feed on Tf. Scale bars represent: A-G, $20 \mu \mathrm{m}$.

trophic dinoflagellates Gyrodinium sp. (approximately $60-80 \mu \mathrm{m}$ in cell length) and Gyrodinium sp. (>80 $\mu \mathrm{m}$ in cell length), both 2.0 cells $\mathrm{mL}^{-1}$, were observed at $5 \mathrm{~m}$ of Station 504, where an abundance of the heterotrophic dinoflagellates Protoperidinium spp., 1.0 cells $\mathrm{mL}^{-1}$, was found (Table 4). The maximum abundance of the heterotrophic dinoflagellates was 5.0 cells $\mathrm{mL}^{-1}$. The highest abundance of total tintinnids, 2.1 cells $\mathrm{mL}^{-1}$, was found at $20 \mathrm{~m}$ at Station 504, and Leprotintinnus nordqvistii was the most dominant tintinnid (Table 4). Naked ciliates $>50$ $\mu \mathrm{m}$ were found within $10 \mathrm{~m}$ at Station 504, with a maximum abundance of 1.8 cells $\mathrm{mL}^{-1}$ (Table 4 ).

\section{DISCUSSION}

Prior to the present study, the mixotrophic dinoflagellate Fragilidium subglobosum and heterotrophic dinoflagellates Noctiluca scintillans, Polykrikos kofoidii, and Protoperidinium steinii were reported to feed on T. furca (Hansen and Nielsen 1997, Jeong et al. 2001, Olseng et al. 2002, Drits et al. 2013). Fragilidium spp. are known to engulf whole prey through the sulcal area, $N$. scintillans engulf prey cell using mucus attached to the tentacle, and Polykrikos spp. engulf prey cells after anchoring the prey with a nematocyst-taeniocyst complex (Kiфrboe 
and Titelman 1998, Hansen and Calado 1999, Tillmann and Hoppenrath 2013). However, Protoperidinium spp. feed on prey cells wrapped in pallium after anchoring prey using a tow filament (Jacobson and Anderson 1992, Hansen and Calado 1999). Interestingly, the results of the present study clearly showed that among the common heterotrophic protist predators tested, only pedunclefeeders Aduncodinium glandula, Luciella masanensis, and Pfiesteria piscicida ingested T. furca TFDD1808. In contrast, the engulfment feeders Gyrodinium dominans, G. jinhaense, G. moestrupii, and Oxyrrhis marina, the filter feeder Rimostrombidium sp., and the pallium feeder Oblea rotunda did not consume T. furca. However, not all peduncle feeders were successful at feeding on T. furca; one of the peduncle feeders, Gyrodiniellum shiwhaense, failed to ingest $T$. furca. Therefore, feeding mechanisms may not be primarily responsible for the ability and inclination of these common heterotrophic protists to feed on T. furca. Cells of A. glandula are known to feed on diverse prey items, including perch blood cells and many algal prey species (Jang et al. 2016). The results of the present study extend the prey species of A. glandula to T. furca. Cells of L. masanensis and P. piscicida are known to feed on dinoflagellate prey species of $\leq 9.7 \mu \mathrm{m}$ in the equivalent spherical diameter (ESD) and athecate dinoflagellates such as Margalefidinium polykrikoides, Akashiwo sanguinea, and Gymnodinium catenatum, but they did not feed on thecate dinoflagellates $\geq 12.1 \mu \mathrm{m}$ (Jeong et al. 2007). You et al. (2020) reported that P. piscicida fed on larger sized thecate dinoflagellates, but only on motionless cells. Thus, the present study is the first to report that L. masanensis and P. piscicida are able to feed on a moving thecate dinoflagellate $\geq 12.1 \mu \mathrm{m}$ because the ESD of T. furca is approximately $29 \mu \mathrm{m}$ (Jeong et al. 2001). Cells of L. masanensis and P. piscicida swarmed to feed on a $T$. furca cell. Other peduncle feeding heterotrophic dinoflagellates Stoeckeria algicida and Stoeckeria changwonensis are known to swarm to feed on a prey cell (Jeong et al. 2005, Lim et al. 2014). Their distinctive swarming behaviors may be triggered by the chemosensory signals from prey (Burkholder and Glasgow 1995, Lewitus et al. 1999).

Among the heterotrophic protists that did not predate T. furca in the present study, G. shiwhaense, G. dominans, and Rimostrombidium sp. did not attempt to attack T. fur$c a$, whereas the other heterotrophic protists attempted to feed on T. furca cells. Thus, G. shiwhaense, G. dominans, and Rimostrombidium sp. may not have enzymes related to the detection of T. furca cells. Cells of G. jinhaense are known not to feed on microalgae $>26 \mu \mathrm{m}$ in ESD, except the dinoflagellate Lingulodinium polyedra, where ESD is approximately $38 \mu \mathrm{m}$ (Kang et al. 2020). Thus, G. jinhaense may have difficulty engulfing T. furca cells. Furthermore, G. moestrupii cells were also observed to have difficulty in utilizing long T. furca cells as prey, although G. moestrupii is known to feed on L. polyedra (Kang et al. 2020). Cells of $O$. rotunda and O. marina successfully target dinoflagellate prey species $<27 \mu \mathrm{m}$ in ESD, respectively (Strom and Buskey 1993, Kang et al. 2019, Kim et al. 2019, You et al. 2020). Therefore, the elongated horns, and large size of $T$. furca may be partially responsible for nonfeeding by these heterotrophic dinoflagellates.

Aduncodinium glandula, L. masanensis, and P. piscicida were not found in the water samples collected from two stations on Jul 31, 2020. In the present study, T. furca did not support the positive growth of these three heterotrophic dinoflagellates. Therefore, the results of the feeding experiments in the present study may provide an explanation for the non-detection of these three heterotrophic dinoflagellates in the water samples. The heterotrophic dinoflagellates Gyrodinium sp. $(>80 \mu \mathrm{m})$ and Pro-

Table 5. The lorical oral diameter (LOD) of the tintinnids $s^{\mathrm{a}}$, the maximum ingestible prey size (MIP) ${ }^{\mathrm{b}}$ of each tintinnid, and the dimension of Triposfurca

\begin{tabular}{|c|c|c|c|}
\hline & LOD or length $(\mu \mathrm{m})$ & MIP or width $(\mu \mathrm{m})$ & Reference \\
\hline \multicolumn{4}{|l|}{ Tintinnid ciliate species } \\
\hline Tintinnopsis akkeshiensis & $24-34$ & $10.3-14.6$ & Hada (1937) \\
\hline Leprotintinnus nordqvistii & $30-38$ & $12.9-16.3$ & Abou Zaid and Hellal (2012) \\
\hline Tintinnopsis tubulosoides & $32-36$ & $13.8-15.5$ & Feng et al. (2018) \\
\hline Tintinnopsis kofoidi & $33-35$ & $14.2-15.1$ & Hada (1937) \\
\hline Tintinnopsis lohmanni & $35-52$ & $15.1-22.4$ & Hada (1937) \\
\hline Tintinnopsis radix & 45 & 19.4 & Hada (1937) \\
\hline \multicolumn{4}{|l|}{ Mixotrophic flagellate } \\
\hline Tripos furca & $100-200$ & $30-50$ & Baek et al. (2008) \\
\hline
\end{tabular}

${ }^{\mathrm{a}}$ Species observed in the study region on Jul 31, 2020.

${ }^{\mathrm{b}}$ Maximum ingestible prey size was calculated according to Heinbokel (1978). 
toperidinium spp. and two tintinnid ciliates were found in the water samples collected from Station 501, at which the maximum abundance of $T$. furca was 130.8 cells $\mathrm{mL}^{-1}$. Meanwhile, Gyrodinium spp. ( $\geq 60 \mu \mathrm{m})$, Noctiluca scintillans, Protoperidinium spp., and several tintinnid species were found in the water samples collected from Station 504, at which the maximum abundance of T. furca was 59.2 cells $\mathrm{mL}^{-1}$. Furthermore, the abundances of Gyrodinium spp. $(\geq 60 \mu \mathrm{m}), N$. scintillans, Protoperidinium spp., and several tintinnid species at Station 504 were as low as $0.6-2.0$ cells $\mathrm{mL}^{-1}$. In contrast, Polykrikos kofoidii was not found in these water samples. Jeong et al. (2001) reported that $P$. kofoidii grew on T. furca with a maximum growth rate of $0.35 \mathrm{~d}^{-1}$, and half-saturation constant (the prey concentration sustaining $1 / 2$ maximum growth rate) and the threshold prey concentration of $P$. kofoidii feeding on T. furca was $128 \mathrm{ng} \mathrm{C} \mathrm{mL}^{-1}$ (102 cells $\mathrm{mL}^{-1}$ ) and $113 \mathrm{ng} \mathrm{C}$ $\mathrm{mL}^{-1}\left(90\right.$ cells $\left.\mathrm{mL}^{-1}\right)$, respectively. When the abundance of T. furca was 59.2 and 130.8 cells $\mathrm{mL}^{-1}$, the growth rates of P. kofoidii feeding on T. furca, calculated using the equation of Jeong et al. (2001), were -0.153 and $0.101 \mathrm{~d}^{-1}$, respectively. Therefore, low abundances of $T$. furca during the study period may be partially responsible for the lack of detection of Polykrikos spp.

The naked ciliate Rimostrombidium sp. (oral diameter $=29.4 \mu \mathrm{m}, \mathrm{n}=6$ ) did not consume T. furca. The large tintinnid ciliates Favella philippinensis and Favella ehrenbergii (lorical oral diameter $[\mathrm{LOD}]=69-144 \mu \mathrm{m}$ ) are known to engulf Tripos sp., while the small tintinnid ciliate Tintinnopsis uruguayensis $(\mathrm{LOD}=37-42 \mu \mathrm{m})$ is unable to feed on T. furca (Godhantaraman and Krishnamurthy 1997, Sivasankar et al. 2017). The LOD of tintinnids is known to strongly correlate with the maximum and optimal prey size (Dolan 2010). In general, tintinnids are known to ingest maximum prey size up to roughly $43 \%$ of their LOD (Heinbokel 1978). To ingest whole T. furca cells, the LOD of tintinnids should be wider than approximately $70 \mu \mathrm{m}$. However, the tintinnids found in the sample waters (LOD = 24-52 $\mu \mathrm{m}$ ) may not be large enough to feed on T. furca (Table 5). Thus, in the collected waters, the tintinnid ciliates may not be large enough to engulf $T$. furca. Therefore, $T$. furca was unlikely to support the rapid growth of the tintinnids at Stations 501 and 504 on Jul 31, 2020.

Conclusively, among the nine common heterotrophic dinoflagellates and one naked ciliate tested in the present study, only A. glandula, L. masanensis, and P. piscicida were found to feed on T. furca. However, T. furca did not support the positive growth of any of these predator species. Furthermore, the abundances of the heterotrophic protists that were able to feed on T. furca were low at
Stations 501 and 504 on Jul 31, 2020. Therefore, predators may not significantly reduce the abundance of $T$. furca, which may be partially responsible for the prevalence of T. furca on the coast of the South Sea from June to September 2020

\section{ACKNOWLEDGEMENTS}

We thank Ju Young Park, Dong Gyu Lee, and Eun Chong Park for technical support. This research was supported by the Useful Dinoflagellate program of Korea Institute of Marine Science and Technology Promotion funded by the Ministry of Oceans and Fisheries and the National Research Foundation funded by the Ministry of Science and ICT (NRF-2017R1E1A1A01074419; NRF2020M3F6A1110582) award to HJJ.

\section{CONFLICTS OF INTEREST}

The authors declare that they have no potential conflicts of interest.

\section{REFERENCES}

Abou Zaid, M. M. \& Hellal, A. M. 2012. Tintinnids (Protozoa: Ciliata) from the coast of Hurghada Red Sea, Egypt. Egypt. J. Aquat. Res. 38:249-268.

Anderson, D. M. 1997. Turning back the harmful red tide. Nature 388:513-514.

Azanza, R. V., Fukuyo, Y., Yap, L. G. \& Takayama, H. 2005. Prorocentrum minimum bloom and its possible link to a massive fish kill in Bolinao, Pangasinan, Northern Philippines. Harmful Algae 4:519-524.

Baek, S. H., Shimode, S. \& Kikuchi, T. 2008. Growth of dinoflagellates, Ceratium furca and Ceratium fusus in Sagami Bay, Japan: the role of temperature, light intensity and photoperiod. Harmful Algae 7:163-173.

Baek, S. H., Shin, H. H., Choi, H. -W., Shimode, S., Hwang, O. M., Shin, K. \& Kim, Y. -O. 2011. Ecological behavior of the dinoflagellate Ceratium furca in Jangmok harbor of Jinhae Bay, Korea. J. Plankton Res. 33:1842-1846.

Bockstahler, K. R. \& Coats, D. W. 1993. Spatial and temporal aspects of mixotrophy in Chesapeake Bay dinoflagellates. J. Eukaryot. Microbiol. 40:49-60.

Burkholder, J. M. \& Glasgow, H. B. Jr. 1995. Interactions of a toxic estuarine dinoflagellate with microbial predators and prey. Arch. Protistenkd. 145:177-188. 
Dodge, J. D. \& Marshall, H. G. 1994. Biogeographic analysis of the armored planktonic dinoflagellate Ceratium in the North Atlantic and adjacent seas. J. Phycol. 30:905-922.

Dolan, J. R. 2010. Morphology and ecology in tintinnid ciliates of the marine plankton: correlates of lorica dimensions. Acta Protozool. 49:235-244.

Drits, A. V., Nikishina, A. B., Sergeeva, V. M. \& Solov'ev, K. A. 2013. Feeding, respiration, and excretion of the Black Sea Noctiluca scintillans MacCartney in summer. Oceanology 53:442-450.

Feng, M., Wang, C., Zhang, W., Zhang, G., Xu, H., Zhao, Y., Xiao, T., Wang, C., Wang, W., Bi, Y. \& Liang, J. 2018. Annual variation of species richness and lorica oral diameter characteristics of tintinnids in a semi-enclosed bay of western Pacific. Estuar. Coast. Shelf Sci. 207:164-174.

Flewelling, L. J., Naar, J. P., Abbott, J. P., Baden, D. G., Barros, N. B., Bossart, G. D., Bottein, M. -Y. D., Hammond, D. G., Haubold, E. M., Heil, C. A., Henry, M. S., Jacocks, H. M., Leighfield, T. A., Pierce, R. H., Pitchford, T. D., Rommel, S. A., Scott, P. S., Steidinger, K. A., Truby, E. W., Van Dolah, F. M. \& Landsberg, J. H. 2005. Red tides and marine mammal mortalities. Nature 435:755-756.

Godhantaraman, N. \& Krishnamurthy, K. 1997. Experimental studies on food habits of tropical microzooplankton: (prey-predator interrelationship). Indian J. Mar. Sci. 26:345-349.

Hada, Y. 1937. The fauna of Akkeshi Bay: IV. The pelagic ciliata (with 56 textfigures). J. Fac. Sci. Hokkaido Imp. Univ. Ser. 5:143-216.

Hansen, P. J. 1991. Quantitative importance and trophic role of heterotrophic dinoflagellates in a coastal pelagial food web. Mar. Ecol. Prog. Ser. 73:253-261.

Hansen, P. J. 1992. Prey size selection, feeding rates and growth dynamics of heterotrophic dinoflagellates with special emphasis on Gyrodinium spirale. Mar. Biol. 114:327-334.

Hansen, P. J. \& Calado, A. J. 1999. Phagotrophic mechanisms and prey selection in free-living dinoflagellates. J. Eukaryot. Microbiol. 46:382-389.

Hansen, P. J. \& Nielsen, T. G. 1997. Mixotrophic feeding of Fragilidium subglobosum (Dinophyceae) on three species of Ceratium: effects of prey concentration, prey species and light intensity. Mar. Ecol. Prog. Ser. 147:187196.

Heinbokel, J. F. 1978. Studies on the functional role of tintinnids in the Southern California Bight. II. Grazing rates of field populations. Mar. Biol. 47:191-197.

Horner, R. A., Garrison, D. L. \& Plumley, F. G. 1997. Harmful algal blooms and red tide problems on the U.S. west coast. Limnol. Oceanogr. 42:1076-1088.
Jacobson, D. M. \& Anderson, D. M. 1992. Ultrastructure of the feeding apparatus and myonemal system of the heterotrophic dinoflagellate Protoperidinium spinulosum. J. Phycol. 28:69-82.

Jakobsen, H. H. \& Tang, K. W. 2002. Effects of protozoan grazing on colony formation in Phaeocystis globosa (Prymnesiophyceae) and the potential costs and benefits. Aquat. Microb. Ecol. 27:261-273.

Jang, S. H., Jeong, H. J., Lim, A. S., Kwon, J. E. \& Kang, N. S. 2016. Feeding by the newly described heterotrophic dinoflagellate Aduncodinium glandula: having the most diverse prey species in the family Pfiesteriaceae. Algae 31:17-31.

Jeong, H. J., Ha, J. H., Yoo, Y. D., Park, J. Y., Kim, J. H., Kang, N. S., Kim, T. H., Kim, H. S. \& Yih, W. H. 2007. Feeding by the Pfiesteria-like heterotrophic dinoflagellate Luciella masanensis. J. Eukaryot. Microbiol. 54:231-241.

Jeong, H. J., Kang, H. C., Lim, A. S., Jang, S. H., Lee, K., Lee, S. Y., Ok, J. H., You, J. H., Kim, J. H., Lee, K. H., Park, S. A., Eom, S. H., Yoo, Y. D. \& Kim, K. Y. 2021. Feeding diverse prey as an excellent strategy of mixotrophic dinoflagellates for global dominance. Sci. Adv. 7:eabe4214.

Jeong, H. J., Kim, J. S., Kim, J. H., Kim, S. T., Seong, K. A., Kim, T. H., Song, J. Y. \& Kim, S. K. 2005. Feeding and grazing impact of the newly described heterotrophic dinoflagellate Stoeckeria algicida on the harmful alga Heterosigma akashiwo. Mar. Ecol. Prog. Ser. 295:69-78.

Jeong, H. J., Kim, S. K., Kim, J. S., Kim, S. T., Yoo, Y. D. \& Yoon, J. Y. 2001. Growth and grazing rates of the heterotrophic dinoflagellate Polykrikos kofoidii on red-tide and toxic dinoflagellates. J. Eukaryot. Microbiol. 48:298-308.

Jeong, H. J. \& Latz, M. I. 1994. Growth and grazing rates of the heterotrophic dinoflagellates Protoperidinium spp. on red tide dinoflagellates. Mar. Ecol. Prog. Ser. 106:173185.

Jeong, H. J., Lee, K. H., Yoo, Y. D., Kang, N. S. \& Lee, K. 2011. Feeding by the newly described, nematocyst-bearing heterotrophic dinoflagellate Gyrodiniellum shiwhaense. J. Eukaryot. Microbiol. 58:511-524.

Jeong, H. J., Lim, A. S., Franks, P. J. S., Lee, K. H., Kim, J. H., Kang, N. S., Lee, M. J., Jang, S. H., Lee, S. Y., Yoon, E. Y., Park, J. Y., Yoo, Y. D., Seong, K. A., Kwon, J. E. \& Jang, T. Y. 2015. A hierarchy of conceptual models of red-tide generation: nutrition, behavior, and biological interactions. Harmful Algae 47:97-115.

Jeong, H. J., Lim, A. S., Lee, K., Lee, M. J., Seong, K. A., Kang, N. S., Jang, S. H., Lee, K. H., Lee, S. Y., Kim, M. O., Kim, J. H., Kwon, J. E., Kang, H. C., Kim, J. S., Yuh, W., Shin, K., Jang, P. K., Ryu, J. -H., Kim, S. Y., Park, J. Y. \& Kim, K. Y. 2017. Ichthyotoxic Cochlodinium polykrikoides red tides off- 
shore in the South Sea, Korea in 2014: I. Temporal variations in three-dimensional distributions of red-tide organisms and environmental factors. Algae 32:101-130.

Jeong, H. J., Yoo, Y. D., Lee, K. H., Kim, T. H., Seong, K. A., Kang, N. S., Lee, S. Y., Kim, J. S., Kim, S. \& Yih, W. H. 2013. Red tides in Masan Bay, Korea in 2004-2005: I. Daily variations in the abundance of red-tide organisms and environmental factors. Harmful Algae 30(Suppl. 1):S75-S88.

Jessup, D. A., Miller, M. A., Ryan, J. P., Nevins, H. M., Kerkering, H. A., Mekebri, A., Crane, D. B., Johnson, T. A. \& Kudela, R. M. 2009. Mass stranding of marine birds caused by a surfactant-producing red tide. PLoS ONE 4:e4550.

Johnson, M. D., Stoecker, D. K. \& Marshall, H. G. 2013. Seasonal dynamics of Mesodinium rubrum in Chesapeake Bay. J. Plankton Res. 35:877-893.

Kang, H. C., Jeong, H. J., Jang, S. H. \& Lee, K. H. 2019. Feeding by common heterotrophic protists on the phototrophic dinoflagellate Biecheleriopsis adriatica (Suessiaceae) compared to that of other suessioid dinoflagellates. Algae 34:127-140.

Kang, H. C., Jeong, H. J., Park, S. A., Eom, S. H., Ok, J. H., You, J. H., Jang, S. H. \& Lee, S. Y. 2020. Feeding by the newly described heterotrophic dinoflagellate Gyrodinium jinhaense: comparison with G. dominans and G. moestrupii. Mar. Biol. 167:156.

Kim, S. J., Jeong, H. J., Kang, H. C., You, J. H. \& Ok, J. H. 2019. Differential feeding by common heterotrophic protists on four Scrippsiella species of similar size. J. Phycol. 55:868-881.

Kiфrboe, T. \& Titelman, J. 1998. Feeding, prey selection and prey encounter mechanisms in the heterotrophic dinoflagellate Noctiluca scintillans. J. Plankton Res. 20:16151636.

Landsberg, J. H. 2002. The effects of harmful algal blooms on aquatic organisms. Rev. Fish. Sci. 10:113-390.

Lee, C. -K., Park, T. -G., Park, Y. -T. \& Lim, W. -A. 2013. Monitoring and trends in harmful algal blooms and red tides in Korean coastal waters, with emphasis on Cochlodinium polykrikoides. Harmful Algae 30(Suppl. 1):S3-S14.

Lewitus, A. J., Glasgow, H. B. Jr. \& Burkholder, J. M. 1999. Kleptoplastidy in the toxic dinoflagellate Pfiesteria piscicida (Dinophyceae). J. Phycol. 35:303-312.

Lim, A. S., Jeong, H. J., Jang, T. Y., Yoo, Y. D., Kang, N. S., Yoon, E. Y. \& Kim, G. H. 2014. Feeding by the newly described heterotrophic dinoflagellate Stoeckeria changwonensis: a comparison with other species in the family Pfiesteriaceae. Harmful Algae 36:11-21.

Lim, A. S., Jeong, H. J., Seong, K. A., Lee, M. J., Kang, N. S., Jang, S. H., Lee, K. H., Park, J. Y., Jang, T. Y. \& Yoo, Y. D.
2017. Ichthyotoxic Cochlodinium polykrikoides red tides offshore in the South Sea, Korea in 2014: II. Heterotrophic protists and their grazing impacts on redtide organisms. Algae 32:199-222.

Lowe, C. D., Montagnes, D. J. S., Martin, L. E. \& Watts, P. C. 2010. Patterns of genetic diversity in the marine heterotrophic flagellate Oxyrrhis marina (Alveolata: Dinophyceae). Protist 161:212-221.

Mason, P. L., Litaker, R. W., Jeong, H. J., Ha, J. H., Reece, K. S., Stokes, N. A., Park, J. Y., Steidinger, K. A., Vandersea, M. W., Kibler, S., Tester, P. A. \& Vogelbein, W. K. 2007. Description of a new genus of Pfiesteria-like dinoflagellate, Luciella gen. nov. (Dinophyceae), including two new species: Luciella masanensis sp. nov. and Luciella atlantis sp. nov. J. Phycol. 43:799-810.

Menden-Deuer, S. \& Lessard, E. J. 2000. Carbon to volume relationships for dinoflagellates, diatoms, and other protist plankton. Limnol. Oceanogr. 45:569-579.

Nakamura, Y., Yamazaki, Y. \& Hiromi, J. 1992. Growth and grazing of a heterotrophic dinoflagellate, Gyrodinium dominans, feeding on a red tide flagellate, Chattonella antiqua. Mar. Ecol. Prog. Ser. 82:275-279.

Ok, J. H., Jeong, H. J., Lim, A. S. \& Lee, K. H. 2017. Interactions between the mixotrophic dinoflagellate Takayama helix and common heterotrophic protists. Harmful Algae 68:178-191.

Olseng, C. D., Naustvoll, L. -J. \& Paasche, E. 2002. Grazing by the heterotrophic dinoflagellate Protoperidinium steinii on a Ceratium bloom. Mar. Ecol. Prog. Ser. 225:161-167.

Roberts, E. C., Wootton, E. C., Davidson, K., Jeong, H. J., Lowe, C. D. \& Montagnes, D. J. S. 2011. Feeding in the dinoflagellate Oxyrrhis marina: linking behaviour with mechanisms. J. Plankton Res. 33:603-614.

Shumway, S. E. 1990. A review of the effects of algal blooms on shellfish and aquaculture. J. World Aquac. Soc. 21:65104.

Shumway, S. E., Allen, S. M. \& Boersma, P. D. 2003. Marine birds and harmful algal blooms: sporadic victims or under-reported events? Harmful Algae 2:1-17.

Sivasankar, R., Kumar, P. S., Ezhilarasan, P., Naidu, S. A., Rao, G. D., Kanuri, V. V., Ranga Rao, V. \& Ramu, K. 2017. Swarm of Tintinnopsis uruguayensis in the estuarine waters of Kochi, Southwest coast of India. Food Webs 13:30-32.

Smalley, G. W. \& Coats, D. W. 2002. Ecology of the red-tide dinoflagellate Ceratium furca: distribution, mixotrophy, and grazing impact on ciliate populations of Chesapeake Bay. J. Eukaryot. Microbiol. 49:63-73.

Smalley, G. W., Coats, D. W. \& Adam, E. J. 1999. A new method using fluorescent microspheres to determine grazing on ciliates by the mixotrophic dinoflagellate Ceratium 
furca. Aquat. Microb. Ecol. 17:167-179.

Smalley, G. W., Coats, D. W. \& Stoecker, D. K. 2003. Feeding in the mixotrophic dinoflagellate Ceratium furca is influenced by intracellular nutrient concentrations. Mar. Ecol. Prog. Ser. 262:137-151.

Sonntag, B., Posch, T., Klammer, S., Teubner, K. \& Psenner, R. 2006. Phagotrophic ciliates and flagellates in an oligotrophic, deep, alpine lake: contrasting variability with seasons and depths. Aquat. Microb. Ecol. 43:193-207.

Stoecker, D. K. 1999. Mixotrophy among Dinoflagellates. J. Eukaryot. Microbiol. 46:397-401.

Stoecker, D. K., Thessen, A. E. \& Gustafson, D. E. 2008. “Windows of opportunity" for dinoflagellate blooms: reduced microzooplankton net growth coupled to eutrophication. Harmful Algae 8:158-166.

Strom, S. L. \& Buskey, E. J. 1993. Feeding, growth, and behavior of the thecate heterotrophic dinoflagellate Oblea rotunda. Limnol. Oceanogr. 38:965-977.

Tillmann, U. \& Hoppenrath, M. 2013. Life cycle of the pseudocolonial dinoflagellate Polykrikos kofoidii (Gymnodiniales, Dinoflagellata). J. Phycol. 49:298-317.

Tomas, C. R. 1997. Identifying marine phytoplankton. Academic Press, San Diego, CA, 858 pp.

Turner, J. T. 2006. Harmful algae interactions with marine planktonic grazers. In Granéli, E. \& Turner, J. T. (Eds.)
Ecology of Harmful Algae: Ecological Studies (Analysis and Synthesis). Springer, Berlin, pp. 259-270.

Watras, C. J., Garcon, V. C., Olson, R. J., Chisholm, S. W. \& Anderson, D. M. 1985. The effect of zooplankton grazing on estuarine blooms of the toxic dinoflagellate Gonyaulax tamarensis. J. Plankton Res. 7:891-908.

Welch, P. S. 1948. Limnological methods. Blakiston Co., Philadelphia, PA, 381 pp.

Wood, E. J. F. 1954. Dinoflagellates in the Australian region. Aust. J. Mar. Freshw. Res. 5:171-352.

Yang, J., Löder, M. G. J., Jiang, Y. \& Wiltshire, K. H. 2019. Are tintinnids picky grazers: feeding experiments on a mixture of mixotrophic dinoflagellates and implications for red tide dynamics. Mar. Pollut. Bull. 149:110488.

Yoo, Y. D., Jeong, H. J., Kim, J. S., Kim, T. H., Kim, J. H., Seong, K. A., Lee, S. H., Kang, N. S., Park, J. W., Park, J., Yoon, E. Y. \& Yih, W. H. 2013. Red tides in Masan Bay, Korea in 2004-2005: II. Daily variations in the abundance of heterotrophic protists and their grazing impact on red-tide organisms. Harmful Algae 30(Suppl. 1):S89-S101.

You, J. H., Jeong, H. J., Kang, H. C., Ok, J. H., Park, S. A. \& Lim, A. S. 2020. Feeding by common heterotrophic protist predators on seven Prorocentrum species. Algae 35:6178. 